\title{
Prescribing patterns of antiparkinson drugs in a group of Colombian patients, 2015
}

\author{
Jorge Enrique Machado-Alba, Luis Felipe Calvo-Torres, \\ Andrés Gaviria-Mendoza, Juan Daniel Castrillón-Spitia
}

Grupo de Investigación en Farmacoepidemiología y Farmacovigilancia,

Universidad Tecnológica de Pereira-Audifarma, S.A., Pereira, Colombia

\begin{abstract}
Introduction: Parkinson's disease, whose prevalence in Colombia is 4.7 per 1,000 inhabitants, is a public health problem and a therapeutic challenge for health professionals.

Objective: To determine the prescribing patterns of antiparkinson drugs and the variables associated with its use in a population from Colombia.

Materials and methods: We conducted a descriptive cross-sectional study. We selected patients who had been given antiparkinson drugs uninterruptedly between January $1^{\text {st }}$ and March $31^{\text {st }}, 2015$ from a systematized database of approximately 3.5 million people affiliated to the Colombian health system. We included sociodemographic, pharmacologic and comedication variables. For the multivariate analysis, we used the IBM SPSSTM-22 software.

Results: A total of 2,898 patients was included; the mean age was 65.1 years, and $50.7 \%$ were men; $69.4 \%(n=2010)$ of people received monotherapy and $30.6 \%$ combination therapy with two to five antiparkinson drugs. The most frequently prescribed drugs were: levodopa $45.5 \%$ ( $n=1,318$ patients), biperiden $23.1 \%(670)$, amantadine $18.3 \%$ (531) and pramipexole $16.3 \%$ (471). The most commonly used association was levodopa/carbidopa + entacapone $(n=311 ; 10.7 \%)$. Multivariate analysis showed that being male $(\mathrm{OR}=1.56 ; 95 \% \mathrm{Cl}: 1.321-1.837)$, over 60 years $(\mathrm{OR}=1.41 ; 95 \% \mathrm{Cl} 1.112-1.782)$ and receiving treatment in the city of Barranquilla $(\mathrm{OR}=2.23 ; 95 \% \mathrm{Cl} 1.675-2.975)$ were statistically associated with a greater risk of using combination therapy; $68.2 \%(n=1,977)$ patients were given concomitant treatment with other drugs.

Conclusions: Prescribing habits of drugs with high therapeutic value predominated, mainly in antiparkinson drugs monotherapy. Most were employed in the usual recommended doses. It is necessary to explore the clinical effectiveness of the medications studied and differentiate between disease and parkinsonian syndromes subtypes.
\end{abstract}

Key words: Parkinson disease; antiparkinson agents; pharmacoepidemiology; drug prescriptions; drug utilization; Colombia.

doi: https://doi.org/10.7705/biomedica.v38i4.3781

Patrones de prescripción de fármacos antiparkinsonianos en un grupo de pacientes de Colombia, 2015

Introducción. La enfermedad de Parkinson, cuya prevalencia en Colombia es de 4,7 por 1.000 habitantes, constituye un problema de salud pública y un reto terapéutico para los profesionales de la salud.

Objetivo. Determinar los patrones de prescripción de fármacos antiparkinsonianos y las variables asociadas con su utilización en una población colombiana.

Materiales y métodos. Se hizo un estudio descriptivo de corte transversal. A partir de una base de datos de 3,5 millones de afiliados al sistema de salud, se seleccionaron pacientes con prescripción de medicamentos antiparkinsonianos de manera ininterrumpida entre el $1^{\circ}$ de enero y el 31 de marzo de 2015. Se incluyeron variables sociodemográficas, farmacológicas y de medicación concomitante. EI análisis multivariado se hizo con el programa IBM SPSS ${ }^{\mathrm{TM}}-22$.

Resultados. Se hallaron 2.898 pacientes, con una edad media de 65,1 años, de los cuales el 50,7 \% correspondía a hombres. El 69,4\% (n=2.010) de las personas recibía monoterapia y el 30,6 \%, tratamiento combinado con dos a cinco medicamentos antiparkinsonianos. Los más prescritos eran la levodopa ( $45,5 \% ; n=1.318$ pacientes), el biperideno $(23,1 \% ; n=670)$, la amantadina $(18,3 \% ; n=531)$ y el pramipexol $(16,3 \% ; n=471)$. La asociación más utilizada fue la de levodopa-carbidopa y entacapone

\footnotetext{
Author's contributions:
}

All authors participated in the drafting, data collection, data analysis, description and discussion of results, and in the writing of the manuscript. 
$\left(\mathrm{n}=311 ; 10,7 \%\right.$ ). En el análisis multivariado se encontró que ser hombre (odds ratio, $\mathrm{OR}=1,56 ; \mathrm{IC}_{95 \%}$ $1,321-1,837)$, ser mayor de 60 años $\left(O R=1,41 ; I_{95 \%} 1,112-1,782\right)$ y recibir tratamiento en Barranquilla $\left(\mathrm{OR}=2,23 ; \mathrm{IC}_{95 \%} 1,675-2,975\right)$, se asociaban con una mayor probabilidad de emplear el tratamiento combinado. Al $68,2 \%(n=1.977)$ de los pacientes se les había prescrito tratamiento concomitante con otros medicamentos.

Conclusión. Predominaron los hábitos de prescripción de medicamentos con gran valor terapéutico, principalmente en la monoterapia, la mayoría en las dosis usuales recomendadas. Es necesario explorar la efectividad clínica de las prescripciones estudiadas, y diferenciar entre la enfermedad y los subtipos de síndromes parkinsonianos.

Palabras clave: enfermedad de Parkinson; antiparkinsonianos; farmacoepidemiología; prescripciones de medicamentos; utilización de medicamentos; Colombia.

doi: https://doi.org/10.7705/biomedica.v38i4.3781

Parkinson's disease is the second most common movement disorder in the world and the second most frequent neurodegenerative disease. It is characterized by nigrostriatal neuronal loss and the presence of alpha-synuclein inclusion bodies called Lewy bodies, with a subsequent dopamine deficiency (1).

The estimated global incidence is about 4.5-19 cases per 100,000 inhabitants a year and prevalence varies between 71 and 258 cases per 100,000 people as reported by the World Health Organization (WHO). In the case of Europe, the prevalence is $100-200$ cases per 100,000 people $(1,2)$. There is an increased prevalence with advanced age, and between $1 \%$ and $2 \%$ of the population over 65 years suffer from the disease (3-5).

The costs of the pathology in the United Kingdom are estimated to be £3.3 billion and in the United States, the cost per patient per year is about USD\$ 10,000 , which is equivalent to a total cost of the disease of USD $\$ 23$ billion per year (6).

In Colombia, the reported prevalence of Parkinson's disease in those over 50 years of age varies from $1.76(95 \% \mathrm{Cl} 1.66-1.86)$ up to $4.7(95 \% \mathrm{Cl} 2.20-8.90)$ per 1,000 inhabitants, predominantly male (7-9). Through the capture-recapture method, it has been established that of 551 individuals, $80.4 \%$ suffer idiopathic Parkinson's disease and the remaining $19.6 \%$ suffer from Parkinsonian syndrome, including that secondary to drugs. It is estimated that 180,000 persons have the disease in the country, making it a public health problem (10).

\footnotetext{
Corresponding author:

Jorge Enrique Machado-Alba, Grupo de Investigación en Farmacoepidemiología y Farmacovigilancia, Universidad Tecnológica de Pereira, Pereira, Colombia Telephone: (57) (310) 832 6970; fax: (576) 3137822 machado@utp.edu.co
}

Received: 30/01/17; accepted: 21/03/18
Today, the options for providing drug treatment have increased extensively, with around a dozen of active principles grouped into six different pharmacological groups, which are used not only in Parkinson's disease but in other Parkinsonian syndromes and in the drug-induced type, among other indications.

The Colombian health system (Sistema General de Seguridad Social en Salud, SGSSS) contemplates a list of drugs within the benefit plan for its affiliates that includes several drugs for the above-mentioned morbidities. In this context and given that no studies on the use of these drugs in Colombia was found, the main objective of this study was to determine the prescribing patterns of antiparkinson drugs and the variables associated with their use in the country. This may also help to gain data that could lead to the improvement and update of programs aimed at achieving a proper use of and better patient-targeted treatment.

\section{Materials and methods}

This was a cross-sectional study on the prescribing habits of antiparkinson drugs in a population of approximately 3.5 million people affiliated to the contributory scheme of the SGSSS in five health insurance companies (Empresas Prestadoras de Servicios, EPS), corresponding to about $15.9 \%$ of the active population affiliated to this regime in the country and to $7.2 \%$ of the Colombian population. We analyzed the prescription data of patients treated between $1^{\text {st }}$ January and $31^{\text {st }}$ March of 2015 in 60 Colombian cities.

Data included individuals of all ages and of either sex who were receiving antiparkinson drugs and whose treatment was maintained uninterrupted for at least 3 months. This requirement was meant to ensure that patients complied consistently with the treatment, reflecting tolerability and adherence to the medication, while those people who missed 
prescriptions during the observation period were excluded, as it was considered that these individuals would introduce a bias into a study that aimed to describe patterns of medications continuously.

From the information on the consumption of drugs, systematically obtained by the dispensing company Audifarma, S.A., a database was designed that allowed the collection of the following groups of variables:

1. Sociodemographic: gender, age (adult: 18-64 years old, young-old: 65 to 74 years, old: 75 to 84 years, and oldest-old: 85 or more years) and city;

2. antiparkinson drug: drug name, dosage and quantity delivered.

The defined daily dose (DDD) was used as the unit of measure of the usage of the following drugs, as recommended by the $\mathrm{WHO}$, and expressed as defined daily dose (DHD) per 1,000 inhabitants per day:

a) precursor of dopamine (levodopa-carbidopa, levodopa-benserazide);

b) anticholinergic drug (biperiden);

c) dopamine receptor agonists (cabergoline, rotigotine, pramipexole, etc.);

d) inhibitors of catechol-o-methyl transferase [COMT] (entacapone);

e) N-methyl-D-aspartate [NMDA] receptor antagonist (amantadine), and

f) monoamine oxidase- $B$ inhibitors (selegiline, rasagiline).

The unitary and total costs, and the cost per 1,000 inhabitants/day $(\mathrm{CHD}=[\mathrm{cost} / 365 \times$ number of inhabitants]x 1,000) were used to estimate the economic impact of the dispensation of antiparkinson drugs using the average price of the most commonly used drug presentation and the reference price of the distribution company for different EPS (reference value according to the Bank of the Republic of Colombia: USD $\$ 1=$ COP $\$$ 2,576 Colombian pesos (on 31st March, 2015).

Comedication was accepted as a substitute indicator of chronic disease, considering the following circumstances:

a) antidiabetics and insulins/diabetes mellitus;

b) antiulcer medication/peptic ulcer disease;

c) psychostimulants/apathy, anhedonia and drowsiness; d) antidepressants/depressive disorder;

e) anxiolytics and hypnotics/anxiety or sleep disorders;

f) lipid-lowering medication/dyslipidemia;

g) thyroid hormone/hypothyroidism;

h) nitrovasodilators/ischemic heart disease;

i) diuretics and antihypertensives/hypertension;

j) mood stabilizers/bipolar affective disorder;

k) antipsychotics/psychosis-schizophrenia;

I) antidementia/dementia and Alzheimer's disease;

m) antithyroid medication/hyperthyroidism;

n) anticonvulsants/epilepsy;

o) bronchodilators/asthma or chronic obstructive pulmonary disease;

p) laxative/constipation;

q) antiemetic/nausea;

r) analgesics/pain.

In such cases, the convenience of the association with the antiparkinson drug was analyzed based on the pharmacological effects they may have on comorbidity.

The protocol received the approval of the bioethics committee of the Universidad Tecnológica de Pereira and was classified as "research without risk", safeguarding the identity of the patients according to the recommendations of the Declaration of Helsinki.

The statistical package SPSS ${ }^{\mathrm{TM}}$ Statistics 22.0 (IBM, USA) for Windows was used for data analysis. Descriptive statistics were used: means, standard deviation, minimum and maximum values for continuous variables and percentages for categorical variables. T-test or ANOVA was used for quantitative variables comparison and $\chi^{2}$ for categorical. A logistic regression model was performed using as a dependent variable the use of antiparkinson drugs alone or in combination (yes/ no), and also the need for comedications (yes/no), and as covariates those significantly associated with them in the bivariate analyses. The statistical significance level was determined as $p<0.05$.

\section{Results}

From 2,898 patients affiliated to SGSSS on treatment with antiparkinson drugs for a period of not less than 3 months, the distribution by gender 
showed that $1,468(50.7 \%)$ were men and 1,430 $(49.3 \%)$ women, with a mean age of $65.1 \pm 16.0$ years (rank: 16.5-103.2 years); the distribution by age groups identified 972 adults $(33.5 \%$ of the patients), 519 (17.9\%) young-old, 529 (18.3\%) old and $174(6.9 \%)$ oldest-old. It stood out that 1,570 patients $(54.2 \%)$ were over 60 years of age (figure 1 ).

Table 1 summarizes the prescribing patterns of antiparkinson drugs most frequently used in Colombia. Considered by pharmacological groups, $45.5 \%$ of patients were using levodopa, while $31.6 \%$ received a dopamine agonist. Levodopa-carbidopa and amantadine were being used at usual doses, pramipexole and selegiline were being used above the DDD, while cabergoline and biperiden were below. In this study, no patient was prescribed with pergolide, tolcapone or trihexyphenidyl.

\section{Monotherapy versus combination therapy}

Of the total study patients, $2,010(69.4 \%)$ were prescribed with one, while $888(30.6 \%)$ received a combination of two or more antiparkinsonian agents. There were $687(23.7 \%$ of the total) patients receiving two drugs, $155(5.3 \%)$ receiving three, $44(1.5 \%)$ receiving four, and even two $(0.1 \%)$ patients receiving five of these drugs. Figure 2 shows the relationship between monotherapy and combination therapy for some of the drugs that were evaluated, and that monotherapy was more usual than combination therapy. Statistically significant differences were found between those receiving monotherapy according to sex (women: $74.3 \%$ vs. men: $64.5 \%$; $p<0.001$ ).

Among the 888 patients who were prescribed with antiparkinson drugs combinations, the most frequently used were: levodopa/carbidopa + entacapone ( $n=311 ; 10.7 \%)$, levodopa/carbidopa + amantadine ( $n=152 ; 5.2 \%)$, levodopa/carbidopa + pramipexole $(n=52 ; 1.8 \%)$, and levodopa/carbidopa + biperiden $(n=35 ; 1.2 \%)$. The most common combinations of three of these drugs were: levodopa/carbidopa + entacapone + pramipexole $(n=38 ; 1.3 \%)$, levodopa/carbidopa + entacapone + amantadine $(n=25 ; 0.9 \%)$ followed by levodopa/carbidopa + amantadine + pramipexole ( $n=16 ; 0.5 \%)$.

Multivariate analysis of the relationship between the use of antiparkinson combination therapy and other variables showed that being male, being over 60 years of age, being treated in the city of Barranquilla, and being affiliated with the EPS 1 were statistically associated with a greater likelihood of receiving combined therapy, while being an adult

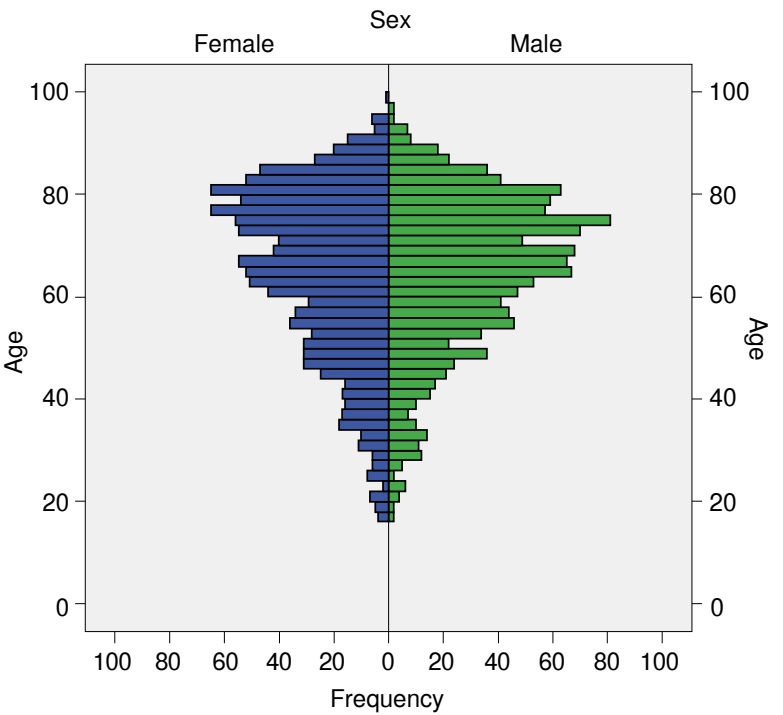

Figure 1. Distribution of 2,898 patients treated with antiparkinson medication by age and sex, Colombia, 2015

between 18 and 64 years was associated with a lower probability of being treated with more than one drug from the group (table 2).

\section{Comedication}

Parkinson's disease and Parkinsonian syndrome are often accompanied by comorbidities that need additional treatment. Among the subjects included, 1,977 patients $(68.2 \%)$ concomitantly received one or more of the following groups of drugs that reflect comorbidity and could interact with some antiparkinsonian agents: antihypertensives ( $n=956 ; 33.0 \%$ of the patients); lipid-lowering drugs $(n=756 ; 26.1 \%)$; analgesics $(n=685 ; 23.6 \%)$; antiulcer medication ( $n=671 ; 23.2 \%)$; diuretics $(n=450 ; 15.5 \%)$; classical antipsychotics $(n=387$; $13.4 \%)$; atypical antipsychotics $(n=381 ; 13.1 \%)$; levothyroxine $(n=355 ; 12.2 \%)$; oral hypoglycemic agents and insulins ( $n=274 ; 9.4 \%$, and from these, $28.5 \%$ were using insulin); atypical antidepressants ( $n=256 ; 8.8 \%)$; benzodiazepines and $z$-drugs $(n=235 ; 8.1 \%)$; lamotrigine and valproic acid $(n=190 ; 6.1 \%)$; laxatives $(n=177 ; 6.1 \%)$; inhaled bronchodilators $(\mathrm{n}=141 ; 4.9 \%)$; gabapentin or pregabalin ( $n=142 ; 4.9 \%)$; tricyclic antidepressants $(n=25 ; 4.3 \%)$; antidemential medications $(n=116$; $4.0 \%)$; metoclopramide ( $n=42 ; 1.4 \%)$; oxybutynin or tolterodine $(n=22 ; 0.8 \%)$. None of the patients received lithium.

No statistically significant differences were found between receiving comedication and sex (male: $68.7 \%$ vs. female: $67.8 \%$ ). A statistically significant 
Table 1. Prescription patterns of antiparkinson drugs used in 2,898 patients in Colombia, 2015

\begin{tabular}{|c|c|c|c|c|c|c|c|}
\hline \multirow[t]{2}{*}{ Medication } & \multicolumn{2}{|c|}{$\begin{array}{l}\text { Prescriptions } \\
\text { /users }\end{array}$} & \multicolumn{2}{|c|}{$\begin{array}{l}\text { Prescribed dose } \\
\text { (mg/day) }\end{array}$} & \multirow{2}{*}{$\begin{array}{c}\text { Sex } \\
\text { ratio } \\
\text { M:F }\end{array}$} & \multirow[t]{2}{*}{$\begin{array}{l}\text { Mean age } \\
\text { (SD) }\end{array}$} & \multirow[t]{2}{*}{ Range } \\
\hline & \# patients & $\%$ & Mean & Mode & & & \\
\hline Levodopa total & 1318 & 45.5 & 563.7 & 500 & $1.2: 1$ & $72.2(11.5)$ & $30-101$ \\
\hline Levodopa/carbidopa tablet & 869 & 30.0 & 600.0 & 500 & $1.2: 1$ & $72.5(11.3)$ & $30-101$ \\
\hline $100+25 \mathrm{mg}$ & 94 & 3.2 & 350.9 & 400 & $0.7: 1$ & $72.3(11.5)$ & $41-99$ \\
\hline $250+25 m g$ & 776 & 26.8 & 629.4 & 500 & $1.3: 1$ & $72.5(11.3)$ & $30-101$ \\
\hline $\begin{array}{l}\text { Levodopa/benserazide tablet } \\
\qquad 200+50 \mathrm{mg}\end{array}$ & 16 & 0.6 & 525.0 & 800 & $0.5: 1$ & $75.4(10.0)$ & $57-91$ \\
\hline $\begin{array}{l}\text { Entacapone/levodopa/carbidopa* } \\
\text { coatedtablet }\end{array}$ & 445 & 15.4 & 712.5 / 479.1 & $600 / 300$ & $1.5: 1$ & $71.3(12.1)$ & 30- 91 \\
\hline $200+100+25 \mathrm{mg}$ & 205 & 7.1 & 609.8 / 304.9 & $600 / 300$ & $1.4: 1$ & $72.4(11.2)$ & $30-89$ \\
\hline $200+150+37.5 \mathrm{mg}$ & 101 & 3.5 & 806.6 / 604.9 & $800 / 600$ & $1.4: 1$ & $68.6(13.4)$ & $31-90$ \\
\hline $200+200+50 \mathrm{mg}$ & 95 & 3.3 & $869.5 / 869.5$ & $800 / 800$ & $2.7: 1$ & $69.5(13.3)$ & 36- 91 \\
\hline $200+50+12.5 \mathrm{mg}$ & 44 & 1.5 & 636.4 / 159.1 & $600 / 150$ & $0.8: 1$ & 74.6 (9.3) & $50-90$ \\
\hline Biperiden tablet 2 mg & 670 & 23.1 & 3.7 & 4 & $1.4: 1$ & $57.4(16.8)$ & $16-101$ \\
\hline Amantadine tablet 100 mg & 531 & 18.3 & 204.7 & 200 & $0.9: 1$ & $69.7(11.9)$ & $27-96$ \\
\hline Pramipexole sustained release tablet & 471 & 16.3 & 2.7 & 3 & $1.0: 1$ & $68.0(10.9)$ & $35-95$ \\
\hline $0.375 \mathrm{mg}$ & 31 & 1.1 & 0.4 & 0.375 & $0.6: 1$ & $67.5(11.7)$ & 46- 82 \\
\hline $0.75 \mathrm{mg}$ & 60 & 2.1 & 0.9 & 0.75 & $0.8: 1$ & $70.1(10.0)$ & 43- 88 \\
\hline $1.5 \mathrm{mg}$ & 116 & 4.0 & 1.7 & 1.5 & $0.8: 1$ & $69.3(11.9)$ & 35- 91 \\
\hline $3.0 \mathrm{mg}$ & 156 & 5.4 & 3.2 & 3 & $1.3: 1$ & $67.5(1.06)$ & $38-95$ \\
\hline $4.5 \mathrm{mg}$ & 111 & 3.8 & 4.6 & 4.5 & $1.5: 1$ & $66.2(10.4)$ & 40-90 \\
\hline Cabergoline tablet $0.5 \mathrm{mg}$ & 205 & 7.1 & 0.1 & 0.07 & $0.2: 1$ & $41.8(11.8)$ & $17-81$ \\
\hline Rotigotine transdermal patch & 142 & 4.9 & 17.8 & 16.8 & $1.1: 1$ & $68.5(10.9)$ & 36- 87 \\
\hline $18 \mathrm{mg}$ & 92 & 3.2 & 20.5 & 16.8 & $1.0: 1$ & $67.1(11.8)$ & $36-85$ \\
\hline $13.5 \mathrm{mg}$ & 27 & 0.9 & 15.2 & 12.6 & $0.9: 1$ & $70.6 \quad(8.1)$ & $51-83$ \\
\hline $9 \mathrm{mg}$ & 26 & 0.9 & 9.2 & 8.4 & $2.3: 1$ & $71.0 \quad(9.8)$ & $51-87$ \\
\hline Rasagiline tablet & 134 & 4.6 & 1.0 & 1 & $1.2: 1$ & $66.5(11.9)$ & $35-95$ \\
\hline $0.5 \mathrm{mg}$ & 23 & 0.8 & 0.6 & 0.5 & $0.9: 1$ & $68.5(10.5)$ & $50-83$ \\
\hline $1 \mathrm{mg}$ & 111 & 3.8 & 1.0 & 1 & $1.2: 1$ & $66.1(12.2)$ & 35- 95 \\
\hline Bromocriptine tablet $2.5 \mathrm{mg}$ & 100 & 3.5 & 4.1 & 2.5 & $0.4: 1$ & $57.1(18.1)$ & 17-103 \\
\hline Selegiline tablet $5 \mathrm{mg}$ & 8 & 0.3 & 9.2 & 10 & $1.7: 1$ & $75.1 \quad(8.5)$ & $65-85$ \\
\hline
\end{tabular}

* Calculations based on entacapone/levodopa; M:F= male:female; SD: Standard deviation

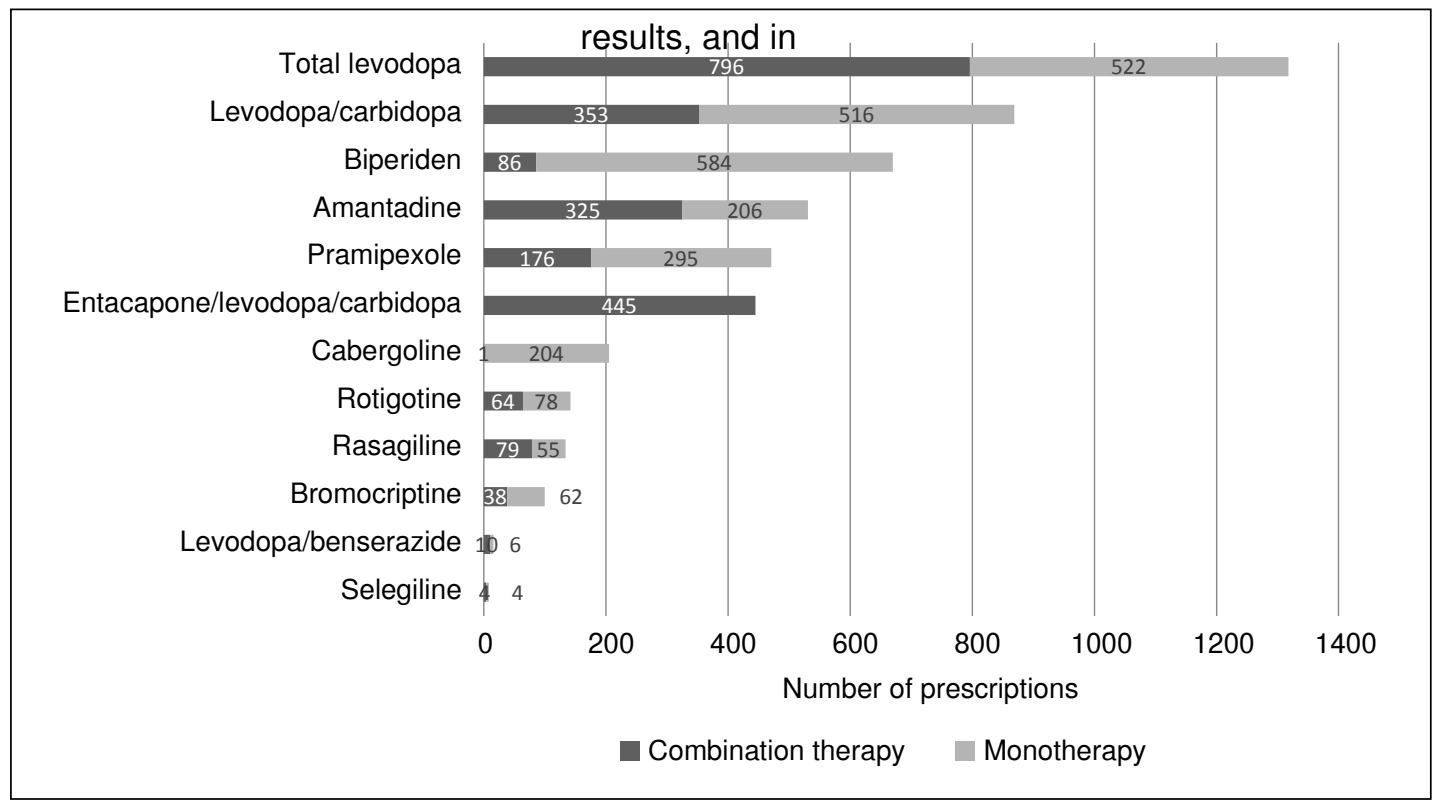

Figure 2. Frequency of antiparkinson medication prescription in combination therapy or monotherapy, Colombia, 2015. 
association was found between receiving biperiden and atypical antipsychotics $(\mathrm{OR}=8.87 ; 95 \% \mathrm{Cl} 6.97$ 11.29 ) and classical antipsychotics (OR=184.17; 95\% Cl 107.99-336.10).

The multivariate analysis of the relationship between the use of comedication and other variables showed that using biperiden, levodopa/ benserazide, rasagiline, and being treated in the cities of Pereira or Palmira were statistically associated with more probability of receiving other drug groups. While the variables being male, the use of amantadine, being treated in the city of
Bogotá and belonging to EPS 1, 2, 3, and 5 were associated with a lower likelihood of receiving any comedication (table 3).

\section{Comparison between cities}

We compared the demographic variables and some prescribing indicators among the 60 Colombian cities included in this study; however, because of the low number of patients in some of them, table 4 only shows the seven largest, where $74.7 \%$ of the people evaluated resided. It can be seen that the differences were significant for the frequency of the use of monotherapy and for the comedication.

Table 2. Multivariate analysis of variables associated with combination treatment in patients on antiparkinson medication, Colombia, 2015

\begin{tabular}{|c|c|c|c|c|c|c|c|c|}
\hline \multirow[t]{2}{*}{ Variables } & \multirow[t]{2}{*}{ B } & \multirow[t]{2}{*}{ SE } & \multirow[t]{2}{*}{ Wald } & \multirow[t]{2}{*}{ DF } & \multirow[t]{2}{*}{ Sig. } & \multirow[t]{2}{*}{ OR } & \multicolumn{2}{|c|}{$95 \% \mathrm{Cl}$} \\
\hline & & & & & & & Lowest & Highest \\
\hline Male sex & 0.443 & 0.08 & 27.75 & 1.00 & $<0.001$ & 1.56 & 1.321 & 1.837 \\
\hline Adult & -0.704 & 0.11 & 38.02 & 1.00 & $<0.001$ & 0.49 & 0.396 & 0.619 \\
\hline Young-old & -0.014 & 0.14 & 0.01 & 1.00 & 0.922 & 0.99 & 0.752 & 1.295 \\
\hline Middle-old & 0.114 & 0.14 & 0.69 & 1.00 & 0.406 & 1.12 & 0.857 & 1.465 \\
\hline$>60$ years & 0.342 & 0.12 & 8.06 & 1.00 & 0.005 & 1.41 & 1.112 & 1.782 \\
\hline City of Barranquilla & 0.803 & 0.15 & 30.03 & 1.00 & $<0.001$ & 2.23 & 1.675 & 2.975 \\
\hline City of Palmira & 0.220 & 0.24 & 0.86 & 1.00 & 0.354 & 1.25 & 0.782 & 1.986 \\
\hline EPS 1 & 0.513 & 0.12 & 18.66 & 1.00 & $<0.001$ & 1.67 & 1.324 & 2.109 \\
\hline EPS 3 & -0.068 & 0.14 & 0.24 & 1.00 & 0.628 & 0.93 & 0.711 & 1.229 \\
\hline EPS 4 & 0.232 & 0.15 & 2.47 & 1.00 & 0.116 & 1.26 & 0.944 & 1.683 \\
\hline Constant & -1.402 & 0.13 & 108.87 & 1.00 & 0.000 & 0.25 & & \\
\hline
\end{tabular}

B: Regression coefficient; SE: Standard error; DF: Degrees of freedom; Sig: Significance; OR: odds ratio; $95 \%$ Cl: Confidence interval of $95 \%$. EPS: Health insurance company

Table 3. Multivariate analysis of variables associated with antiparkinson treatment with comedications, Colombia, 2015

\begin{tabular}{|c|c|c|c|c|c|c|c|c|}
\hline \multirow[t]{2}{*}{ Variables } & \multirow[t]{2}{*}{ B } & \multirow[t]{2}{*}{ SE } & \multirow[t]{2}{*}{ Wald } & \multirow[t]{2}{*}{ DF } & \multirow[t]{2}{*}{ Sig. } & \multirow[t]{2}{*}{ OR } & \multicolumn{2}{|c|}{$95 \% \mathrm{Cl}$} \\
\hline & & & & & & & Lowest & Highest \\
\hline Male sex & -0.34 & 0.10 & 12.25 & 1.00 & $<0.001$ & 0.71 & 0.589 & 0.861 \\
\hline Amantadine use & -0.28 & 0.12 & 5.39 & 1.00 & 0.020 & 0.76 & 0.598 & 0.957 \\
\hline Biperiden use & 3.91 & 0.25 & 249.32 & 1.00 & $<0.001$ & 49.77 & 30.644 & 80.843 \\
\hline Entacapone/levodopa use & 1.77 & 0.15 & 147.84 & 1.00 & $<0.001$ & 5.86 & 4.409 & 7.799 \\
\hline Levodopa/benserazide use & 0.66 & 0.14 & 23.44 & 1.00 & $<0.001$ & 1.93 & 1.481 & 2.527 \\
\hline Levodopa/carbidopa use & -0.08 & 0.55 & 0.02 & 1.00 & 0.887 & 0.93 & 0.317 & 2.698 \\
\hline Rasagiline use & 1.32 & 0.11 & 133.34 & 1.00 & $<0.001$ & 3.73 & 2.985 & 4.667 \\
\hline MAOI use & 0.02 & 0.80 & 0.00 & 1.00 & 0.977 & 1.02 & 0.215 & 4.869 \\
\hline Young-old & -0.32 & 0.77 & 0.17 & 1.00 & 0.678 & 0.73 & 0.159 & 3.309 \\
\hline Bogotá & -0.94 & 0.18 & 26.37 & 1.00 & $<0.001$ & 0.39 & 0.271 & 0.558 \\
\hline Pereira & 0.60 & 0.21 & 8.45 & 1.00 & 0.004 & 1.82 & 1.216 & 2.730 \\
\hline Palmira & 1.03 & 0.36 & 8.16 & 1.00 & 0.004 & 2.79 & 1.380 & 5.638 \\
\hline EPS1 & -1.37 & 0.22 & 40.47 & 1.00 & $<0.001$ & 0.25 & 0.167 & 0.388 \\
\hline EPS2 & -1.43 & 0.23 & 39.59 & 1.00 & $<0.001$ & 0.24 & 0.154 & 0.374 \\
\hline EPS3 & -0.90 & 0.23 & 14.56 & 1.00 & $<0.001$ & 0.41 & 0.258 & 0.647 \\
\hline EPS5 & -1.17 & 0.21 & 31.87 & 1.00 & $<0.001$ & 0.31 & 0.206 & 0.465 \\
\hline Constant & 1.01 & 0.22 & 20.78 & 1.00 & 0.000 & 2.75 & & \\
\hline
\end{tabular}

B: Regression coefficient; S.E.: Standard error; DF: Degrees of freedom; Sig: Significance; OR: Odds ratio; 95\% CI: Confidence interval of 95\%; MAOI: Monoamineoxidase inhibitors; EPS: Health insurance company 
Table 4. Comparison of some demographic variables and prescribing indicators of antiparkinson medications among Colombian cities, 2015

\begin{tabular}{|c|c|c|c|c|c|c|c|c|}
\hline \multirow[t]{2}{*}{ Variable } & Cali & Bogotá & Barranquilla & Pereira & Palmira & Cartagena & Manizales & Colombia \\
\hline & $n=721$ & $n=702$ & $n=311$ & $n=182$ & $n=85$ & $n=83$ & $n=80$ & $n=2898$ \\
\hline Mean age (SD) & $64.6(16.2)$ & $62.9(16.7)$ & $65.5(14.3)$ & $69.7(14.0)$ & $66.9(16.1)$ & $58.7(19.4)$ & $66.3(16.5)$ & $65.1(16.0)$ \\
\hline Male (\%) & 54.6 & 44.3 & 52.7 & 45.6 & 56.5 & 57.8 & 48.8 & 50.7 \\
\hline Monotherapy (\%) & 72.1 & 70.9 & 59.2 & 72.0 & 58.8 & 78.3 & 73.8 & 69.4 \\
\hline Comedication (\%) & 70.6 & 56.8 & 66.2 & 78.6 & 87.1 & 74.7 & 60.0 & 68.2 \\
\hline \multicolumn{9}{|l|}{ Prescription (\%) } \\
\hline Levodopa total & 39.8 & 50.7 & 43.1 & 42.9 & 55.3 & 30.1 & 57.5 & 45.5 \\
\hline Levodopa/carbidopa & 26.1 & 30.6 & 28.6 & 24.2 & 36.5 & 24.1 & 45.0 & 30.0 \\
\hline Biperiden & 35.6 & 6.6 & 19.3 & 13.2 & 35.3 & 44.6 & 7.5 & 23.1 \\
\hline Amantadine & 16.1 & 11.1 & 36.3 & 30.2 & 11.8 & 10.8 & 11.3 & 18.3 \\
\hline Pramipexole & 10.8 & 20.7 & 16.4 & 14.3 & 12.9 & 12.0 & 32.5 & 16.3 \\
\hline $\begin{array}{l}\text { Entacapone/levodopa/ } \\
\text { carbidopa }\end{array}$ & 13.2 & 20.5 & 15.1 & 18.7 & 20.0 & 6.0 & 12.5 & 15.4 \\
\hline Cabergoline & 5.5 & 10.4 & 6.8 & 6.6 & 1.2 & 10.8 & 7.5 & 7.1 \\
\hline Rotigotine & 3.5 & 6.1 & 10.9 & 2.2 & 2.4 & 8.4 & 5.0 & 4.9 \\
\hline Rasagiline & 4.2 & 3.3 & 15.4 & 3.8 & 3.5 & 3.6 & 2.5 & 4.6 \\
\hline Bromocriptine & 2.9 & 5.3 & 0.3 & 2.7 & 3.5 & 1.2 & 8.8 & 2.0 \\
\hline Levodopa/benserazide & 1.1 & 0.0 & 0.0 & 0.0 & 1.2 & 0.0 & 0.0 & 3.5 \\
\hline Selegiline & 0.3 & 0.1 & 0.6 & 0.5 & 0.0 & 0.0 & 0.0 & 0.3 \\
\hline \multicolumn{9}{|c|}{ Mean daily dose to $\mathrm{DDD}$ ratio } \\
\hline Levodopa total & 0.8 & 1.1 & 0.9 & 0.9 & 0.8 & 1.0 & 0.9 & 0.9 \\
\hline Levodopa/carbidopa & 0.9 & 1.1 & 1.0 & 0.9 & 1.0 & 1.0 & 0.9 & 1.0 \\
\hline Biperiden & 0.4 & 0.4 & 0.4 & 0.3 & 0.4 & 0.4 & 0.4 & 0.4 \\
\hline Amantadine & 1.1 & 1.0 & 1.1 & 0.8 & 0.9 & 1.3 & 1.0 & 1.0 \\
\hline Pramipexole & 1.0 & 1.1 & 0.8 & 1.2 & 0.8 & 1.3 & 1.0 & 1.1 \\
\hline $\begin{array}{l}\text { Entacapone/levodopa/ } \\
\text { carbidopa }\end{array}$ & 0.7 & 0.8 & 0.7 & 0.7 & 0.7 & 0.7 & 0.8 & 0.7 \\
\hline Cabergoline & 0.03 & 0.03 & 0.06 & 0.03 & 0.03 & 0.04 & 0.03 & 0.03 \\
\hline Rasagiline & 1.0 & 1.0 & 0.9 & 1.0 & 1.0 & 1.1 & 1.0 & 1.0 \\
\hline Bromocriptine & 0.1 & 0.1 & 0.1 & 0.1 & 0.1 & 0.1 & 0.1 & 0.1 \\
\hline Levodopa/benserazide & 0.8 & - & - & - & 0.7 & - & - & 0.9 \\
\hline Selegiline & 2.0 & 2.0 & 1.8 & 2.0 & - & - & - & 1.8 \\
\hline
\end{tabular}

DDD: Defined daily dose

The consumption of antiparkinson drugs was also presented as a percentage of DDD so that they could be useful in later comparisons.

\section{Economic analysis}

It is estimated that on average 0.231 DDD per 1,000 inhabitants/day of levodopa/carbidopa are consumed, 0.069 DDD per 1,000 inhabitants/day of biperiden and 0.154 DDD of amantadine per 1,000 inhabitants/day. The total cost of dispensing levodopa/carbidopa for the affiliated population per year was COP\$ 167,398,836 (USD $\$ 64,984$ ). The cost of a prescribed daily dose for the 250/25 $\mathrm{mg}$ tablet was COP\$ 331.5 (USD $\$ 0.13$ ), and the CHD was COP\$ 73.4 (USD\$ 0.03), while the daily cost for the 100/25 mg tablet was COP\$ 2,185 (USD\$ 0.85).

The total cost of the dispensation of biperiden to the affiliated population for a year was COP\$ $49,959,408$ (USD $\$ 19,392$ ). The cost of a pre- scribed daily dose for a $2 \mathrm{mg}$ tablet was COP\$ 203.9 (USD $\$ 0.08$ ), and the CHD was COP $\$ 39.3$ (USD\$ 0.02). The total cost of the dispensation of amantadine was COP\$ 172,550,624 (USD\$ $66,984)$. The cost of a prescribed daily dose for $100 \mathrm{mg}$ tablets was COP\$ 903.8 (USD\$ 0.35), and the CHD was COP\$ 135.9 (USD\$ 0.05).

\section{Discussion}

This study allowed us to determine the prescribing patterns of the antiparkinson drugs used most frequently with patients affiliated to the SGSSS of Colombia; these findings can be used by health managers to make decisions aimed at improving the health care of patients with Parkinson's disease and other movement disorders.

The distribution by sex and age of Parkinson's disease worldwide is diverse depending on the study design, geographic location, and ethnicity (1). Studies in Japan and Italy reported that over 
$55.0 \%$ of patients were women $(11,12)$, while in Sweden $53.9 \%$ were men (13). The fact that no sex differences were found after 60 years of age differs from the literature where after this age there is a predominance of males (1).

Levodopa/carbidopa is the most commonly used drug in different studies, and in this case, since it is part of the closed list of drugs that make up the plan of benefits from the SGSSS, its use as gold standard treatment is encouraged (11-13). Otherwise, other medications such as the dopamine agonists, which are not included in this list, had a lower prescription $(11,14)$; but it should be clarified that it is possible to prescribe drugs outside the list, requested through the evaluation of a scientific technical committee or with legal tools for the protection of rights (14). The order of frequency could represent the current recommendations for levodopa use, which is preferred in people over 60 years of age (the most prevalent in this study population), and leaving the use of dopamine agonists for younger patients with the disease $(4,15)$. It is noteworthy that most antiparkinsonian medications are being used at the recommended DDD.

Recent studies have shown similar data on monotherapy $(63.0-71.0 \%)(16)$, but there are also reports of increased use of combination therapy $(50.0 \%)(12)$. In the present work, the most frequent combination corresponds to levodopa/carbidopa plus entacapone, unlike other studies where the levodopa/carbidopa plus dopamine agonist association was the most prescribed $(12,17)$.

The analysis of comorbidities showed that they mostly correspond to common diseases in elderly patients, such as hypertension and dyslipidemia, which is consistent with the mean age of the study patients, although the proportion of patients with diabetes mellitus in this study is lower than expected for this age group in general; however, there have been prevalence reports as low as $1.6 \%$ in patients with Parkinson's disease (12).

It is important to note that a large proportion of patients received analgesics and antiulcer drugs, which is not consistent with results from other studies where comedication with these groups of drugs does not reach $10 \%$. A high consumption of antipsychotics was observed $(26.5 \%$ of the patients), associated with the use of biperiden, an expected outcome as this is a drug commonly used for the management of induced Parkinson, especially by neuroleptics $(3,18)$. In the group of antidepressants, the frequency of use was less than $10 \%$, contrary to those reported in a study with patients diagnosed with Parkinson's disease where depression was identified in about $35 \%$ of patients, which may indicate underdiagnosis in this group of patients (19).

Another important aspect of comedication was the presence of drugs used for the management of non-motor symptoms of Parkinson's that relate especially to autonomic disorders, such as the use of laxatives in constipation, the use of oxybutynin and botulinum toxin for alterations in frequency and urinary urgency, or inhibitors of 5-phosphodiesterase in erectile dysfunction $(0.1 \%$ in this study versus $68.0 \%$ in patients with Parkinson) $(20,21)$. This may be an indicator that non-motor manifestations are not identified in the medical controls of these patients, and worse, they are not being treated, which can affect the patient's quality of life.

The estimated costs of treatment with the major antiparkinson drugs identified in the study were lower than those reported for other populations $(6,22)$, possibly because generic drugs are used in most cases and some of these prices are regulated by the health authorities.

The differences regarding prescribing patterns between different Colombian cities in the study, including the frequencies of use of some antiparkinson medications (table 4), are not surprising, since variability in health care, particularly in prescribing habits, is a constant finding in pharmacoepidemiologic studies (23).

This research has certain limitations regarding the interpretation of some results because the information was obtained from databases and not directly from the patient or the prescriber, and no medical records were consulted, which will be addressed with further drug-utilization studies in the second phase of this research line. It is necessary to collect information about the classification as Parkinson's disease or Parkinsonian syndrome subtype, the incidence of adverse events, adherence to prescribed treatment, the degree of control of symptoms and the impact on the quality of life. Since these variables were not assessed, it is unknown whether the prescription was either needed or appropriate. It is noteworthy that the data come from a captive population receiving drugs on a specific list, so the findings apply to populations with similar characteristics of insurance and health care. 
From the prescribing patterns found in this study, it can be concluded that, in general, the drug-prescribing habits of medications with high therapeutic value included in the list of essential drugs in the country, mainly in monotherapy and at recommended doses, predominate. A significant number of patients receiving classical and atypical antipsychotics was found; this was associated with drug-induced Parkinsonism, which leads to the use of biperiden in particular. Hypertension, dyslipidemia and pain management were the most common comorbid conditions.

It is recommended to conduct new studies to describe the effectiveness of antiparkinson treatment in this group of patients by assessing the relevance of the dosing and the comedication they receive and providing useful tools to reduce the risk of interactions. Meanwhile, programs of continuing medical education including the results of this study can be implemented aimed at treating physicians of this group of patients as a strategy to improve the prescription of antiparkinson drugs, as has been described before for other pathologies (24).

\section{Acknowledgments}

To Viviana Andrea Orozco, Soffy López and Andrea Orozco.

\section{Conflict of interests}

The authors declare that they have no conflict of interests.

\section{References}

1. Alves G, Forsaa EB, Pedersen KF, DreetzGjerstad M, Larsen JP. Epidemiology of Parkinson's disease. J Neurol. 2008;255:18-32. https://doi.org/10.1007/s00415-008-5004-3

2. World Health Organization. Neurological Disorders: Public Health Challenges. Chapter 3: Neurological disorders: A public health approach. Geneva: WHO; 2006. p. 140-8.

3. Nutt JG, Wooten GF. Clinical practice. Diagnosis and initial management of Parkinson's disease. N Engl J Med. 2005;353:1021-7. https://doi.org/10.1056/NEJMcp043908

4. Jankovic J, Poewe W. Therapies in Parkinson's disease. Curr Opin Neurol. 2012;25:433-47. https://doi.org/10.1097/ WCO.0b013e3283542fc2

5. Grupo de Trastornos del Movimiento de la Asociación Colombiana de Neurología. Generalidades de la enfermedad de Parkinson. Acta Neurol Colomb. 2014;30:2-7.

6. Findley LJ. The economic impact of Parkinson's disease. Parkinsonism Relat Disord. 2007;13:S8-S12. https://doi. org/10.1016/j.parkreldis.2007.06.003

7. Takeuchi Y, Guevara JG. Prevalencia de las enfermedades neurológicas en el Valle del Cauca. Estudio Neuroepidemiológico Nacional (EPINEURO). Colomb Med. 1999; 30:74-81.
8. Pradilla AG, Vesga A BE, León-Sarmiento FE, Grupo GENECO. National neuroepidemiological study in Colombia (EPINEURO). Rev Panam Salud Pública. 2003;14:104-11.

9. Sánchez JL, Buriticá O, Pineda D, Uribe CS, Palacio LG. Prevalence of Parkinson's disease and parkinsonism in a Colombian population using the capture-recapture method. Int J Neurosci. 2004;114:175-82. https://doi.org/10. 1080/00207450490269444

10. Diazgranados JA, Chan L, Gómez LF, Lozano AF, Ramírez M. Descripción de la población de pacientes con enfermedad de Parkinson en un centro médico neurológico en la ciudad de Cali, Colombia. Acta Neurol Colomb. 2011;27:205-10

11. Gaida R, Truter I. Prescribing patterns for Parkinson's disease in a South African patient population. J App Pharm Sci. 2014;4:29-34. https://doi.org/10.7324/JAPS.2014.40307

12. Leoni O, Martignoni E, Cosentino M, Michielotto D, Calandrella $\mathrm{D}$, Zangaglia $\mathrm{R}$, et al. Drug prescribing patterns in Parkinson's disease: A pharmacoepidemiological survey in a cohort of ambulatory patients. Pharmacoepidemiol Drug Saf. 2002;11:149-57. https://doi.org/10.1002/pds.682

13. Nakaoka S, Ishizaki T, Urushihara H, Satoh T, Ikeda S, Yamamoto $\mathbf{M}$, et al. Prescribing pattern of anti-Parkinson drugs in Japan: A trend analysis from 2005 to 2010. PloS One. 2014;9:e99021. https://doi.org/10.1371/journal.pone. 0099021

14. Ministerio de Salud y Protección Social. Resolución No. 5926 de 23 de diciembre de 2014. Cited: October 5, 2015. Available in: https://www.minsalud.gov.co/Normatividad_ Nuevo/Resoluci\%C3\%B3n\%205926\%20de\%202014.pdf

15. Connolly BS, Lang AE. Pharmacological treatment of Parkinson disease: A review. JAMA. 2014;311:1670-83. https://doi.org/10.1001/jama.2014.3654

16. Trifirò G, Savica R, Morgante L, Vanacore N, Tari M, Moretti S, et al. Prescribing pattern of anti-Parkinson drugs in Southern Italy: Cross-sectional analysis in the years 2003-2005. Parkinsonism Relat Disord. 2008;14:420-5. https://doi.org/10.1016/j.parkreldis.2007.10.010

17. Tan EK, Yeo AP, Tan V, Pavanni R, Wong MC. Prescribing pattern in Parkinson's disease: Are cost and efficacy overriding factors? Int J Clin Pract. 2005;59:511-4. https:// doi.org/10.1111/j.1368-5031.2005.00426.x

18. Gjerden P, Slordal L, Bramness JG. The use of antipsychotic and anticholinergic antiparkinson drugs in Norway after the withdrawal of orphenadrine. $\mathrm{Br} \mathrm{J}$ Clin Pharmacol. 2009;68:238-42. https://doi.org/10.1111/j.13652125.2009.03446.x

19. Althaus A, Becker OA, Spottke A, Dengler R, Schneider $\mathbf{F}$, Kloss $\mathbf{M}$, et al. Frequency and treatment of depressive symptoms in a Parkinson's disease registry. Parkinsonism Relat Disord. 2008;14:626-32. https://doi.org/10.1016/j. parkreldis.2008.01.016

20. Mostile G, Jankovic J. Treatment of dysautonomia associated with Parkinson's disease. Parkinsonism Relat Disord. 2009;15(Suppl.3):S224-32. https://doi.org/10.1016/S13538020(09)70820-X

21. Seppi K, Weintraub D, Coelho M, Pérez-Lloret S, Fox SH, Katzenschlager $\mathbf{R}$, et al. The movement disorder society evidence-based medicine review update: Treatments for the 
non-motor symptoms of Parkinson's disease. Mov Disord 2011;26(Suppl.3):S42-80. https://doi.org/10.1002/mds.23884

22. Abasolo-Osinaga E, Abecia-Inchaurregui LC, FernándezDíaz E, Barcenilla-Laguna A, Bañares-Onraita T. The prevalence and pharmacological cost of Parkinson's disease in Spain. Rev Neurol. 2006;43:641-5.

23. Machado-Alba JE, Morales-Plaza CD. Patrones de prescripción de antipsicóticos en pacientes afiliados al Sistema
General de Seguridad Social en Salud de Colombia. Biomédica. 2013;33:418-28. https://doi.org/10.1016/10.7705/ biomedica.v33i3.1529

24. Machado-Alba JE, Giraldo-Giraldo C, Machado-Duque ME. Quality of conventional release verapamil prescription in patients with arterial hypertension. Rev Calid Asist. 2015;30:72-8. https://doi.org/10.1016/j.cali.2015.01.009 